University of Nebraska - Lincoln

DigitalCommons@University of Nebraska - Lincoln

\title{
Relationship of surface changes to metal leaching from tungsten composite shot exposed to three different soil types
}

\author{
Deborah Felt \\ US Army Engineer Research and Development Center, deborah.felt@usace.army.mil \\ Steven Larson \\ US Army Engineer Research and Development Center, Steven.I.Larson@usace.army.mil \\ Chris Griggs \\ US Army Engineer Research and Development Center, Chris.S.Griggs@usace.army.mil \\ Catherine Nestler \\ Applied Research Associates, Inc. \\ Michelle Wynter \\ US Army Engineer Research and Development Center, Michelle.Wynter@usace.army.mil
}

Follow this and additional works at: https://digitalcommons.unl.edu/usarmyresearch

Part of the Operations Research, Systems Engineering and Industrial Engineering Commons

Felt, Deborah; Larson, Steven; Griggs, Chris; Nestler, Catherine; and Wynter, Michelle, "Relationship of surface changes to metal leaching from tungsten composite shot exposed to three different soil types" (2011). US Army Research. 122.

https://digitalcommons.unl.edu/usarmyresearch/122

This Article is brought to you for free and open access by the U.S. Department of Defense at DigitalCommons@University of Nebraska - Lincoln. It has been accepted for inclusion in US Army Research by an authorized administrator of DigitalCommons@University of Nebraska - Lincoln. 


\title{
Relationship of surface changes to metal leaching from tungsten composite shot exposed to three different soil types
}

\author{
Deborah Felt $^{\mathrm{a}, *}$, Steven Larson ${ }^{\mathrm{a}}$, Chris Griggs ${ }^{\mathrm{a}}$, Catherine Nestler ${ }^{\mathrm{b}}$, Michelle Wynter $^{\mathrm{a}}$ \\ a US Army Engineer Research and Development Center, 3909 Halls Ferry Road, Vicksburg, MS 39180, USA \\ ${ }^{\mathrm{b}}$ Applied Research Associates, Inc. 119 Monument Place, Vicksburg, MS 39180, USA
}

\section{A R T I C L E I N F O}

\section{Article history:}

Received 5 November 2010

Received in revised form 15 February 2011

Accepted 16 February 2011

Available online $\mathrm{xxxx}$

\section{Keywords:}

Tungsten composite ammunition

Leaching potential

Scanning electron microscopy

Soil type

Soil lysimeter

\begin{abstract}
A B S T R A C T
Physical changes that occur on the surface of fired shots due to firing and impact with soil may increase the dissolution of muniton metals. Increased metal dissolution could potentially increase metal transport and leaching, affecting metal concentrations in surface and groundwater. This research describes the relationship between the surface changes on fired tungsten-nickel-iron ( $94 \% \mathrm{~W}: 2 \% \mathrm{Ni}: 4 \% \mathrm{Fe}$ ) composite shots and metals leaching from those shots. Tungsten composite shot was fired into, and aged in, three soil types (Silty Sand, Sandy Clay, and Silt) in mesoscale rainfall lysimeters to simulate live-fire conditions and subsequent interactions between the metals of the composite and soil. Leachate, runoff, and soil samples were collected from the lysimeters and analyzed for metal content. The shots were analyzed using scanning electron microscopy (SEM) to evaluate surface changes. SEM results indicated that a soil's particle size distribution initially affected the amount of metal that was sheared from the surface of the fired $\mathrm{W}$-composite shots. Shearing was greatest in soils with larger soil particles (sand and gravel); shearing was least in soils composed of small soil particles (fines). Increased metallic shearing from the shot's surface was associated with increased $\mathrm{W}$ dissolution, compared to controls, following a simulated 1 year soil aging.
\end{abstract}

Published by Elsevier Ltd.

\section{Introduction}

Alternatives to lead-based munitions have been developed due to the known environmental risks associated with lead (World Health Organization (WHO), 2003; American Society for Testing and Materials (ASTM), 2007; United States Environmental Protection Agency (USEPA), 2009). Alternative munition formulations based on tungsten (W) have been developed for civilian and military applications (Koutsospyros et al., 2006). Tungsten-based munitions are formulated as composites with other metals such as nickel $(\mathrm{Ni})$, iron $(\mathrm{Fe})$, tin $(\mathrm{Sn})$, copper $(\mathrm{Cu})$, or cobalt $(\mathrm{Co})$. Composites are manufactured by mixing $\mathrm{W}$ powder with the other components and heating or pressing the mixture. The binding materials, which have lower melting points than $\mathrm{W}$, melt first and form a matrix around the $\mathrm{W}$ particles (sintering). The $\mathrm{W}$ remains a powder trapped in the binder matrix. The environmental concern with the $\mathrm{W}$ composites is the potential for $\mathrm{W}$ to react with oxygen and water to form $\mathrm{W}$ oxides (soluble tungstates). If the soluble tungstates dissolve in storm water, they could become either a groundwater or surface water contaminant (Clausen et al., 2007).

\footnotetext{
* Corresponding author. Tel.: +1 601634 3576; fax: +1 6016343518

E-mail addresses: Deborah.Felt@usace.army.mil (D. Felt), Steven.l.Larson@usace. army.mil (S. Larson), Chris.S.Griggs@usace.army.mil (C. Griggs), Chris.S.Griggs@ usace.army.mil (C. Nestler), Michelle.Wynter@usace.army.mil (M. Wynter).
}

There is less environmental concern about the $\mathrm{Fe}$ and $\mathrm{Ni}$ in the composite used in this study. Iron is commonly found in most soils and was present in all three test soils. Nickel is not likely to transport through an environmental system because of its low solubility in water. Elemental Ni does not react with water or air at ambient temperatures, but $\mathrm{Ni}$ can react with halides and other non-metals when heated (Winter 2009). Most Ni compounds, such as nickel oxide, nickel sulfide and nickel tetra carbonyl, are insoluble in water (Occupational Safety and Health Administration (OSHA), 2009).

The type of soil the W-composite shots are fired into directly affects the potential of the metals associated with the composite shots to dissolve, migrate, and possibly impact groundwater and surface water resources. Dermatas et al. (2004) reported that the rate and extent of $\mathrm{W}$ transport appears to vary significantly with soil type. O'Connor et al. (2009) reported that fragmentation of W shots was more likely to occur when the shots were fired into coarser-grained soils. Fragmentation creates small metallic particles that have a larger surface area to mass ratio than intact shots. A larger surface area to mass ratio increases the possibility of dissolution and potential transport of the metals in the environment.

In the current study, the solubility and mobility behavior of a $\mathrm{W}$ composite material ( $94 \% \mathrm{~W}: 2 \% \mathrm{Ni}: 4 \% \mathrm{Fe}$ ) fired into different soil types was investigated using mesoscale laboratory rainfall lysimeters The lysimeter studies provide an accelerated weathering 
evaluation of the presence of metals in soil, leachate, and runoff water. The effect of surface changes in the shot due to firing and soil impact was evaluated using SEM and correlated with soil type and leaching potential.

\section{Materials and methods}

\subsection{Materials}

Reagent grade chemicals, conforming to the specifications of the Committee on Analytical Reagents of the American Chemical Society, were used in all tests. The chemicals were purchased from Fisher Scientific (Pittsburgh, PA, USA) and were used as received.

\subsubsection{W-composite shots}

The W-composite shot is gray in color and is part of the XM $1028120 \mathrm{~mm}$ canister tank round (Supplemental material). The initial weight of a W-composite shot, composed of $94 \% \mathrm{~W}, 2 \% \mathrm{Ni}$, and $4 \% \mathrm{Fe}$, is approximately $8.3 \mathrm{~g}$. The shots were provided by the U.S. Army Research, Development, and Engineering Center, Picatinny Arsenal, NJ.

\subsubsection{Study soils}

Three soils were used in this study. Bulk soil samples collected from two active training range sites were classified as Silty Sand and Sandy Clay. The W-composite shots had been used on one of the ranges and the $\mathrm{W}$-composite shots were scheduled to be used on the other range. The third soil, a Silt soil type (Loess) was included as a reference soil that has been well characterized and is used by researchers at the US Army Engineer Research and Development Center (Davis et al., 2007; Griggs et al., 2007; Felt et al., 2008).

\subsection{Methods}

\subsubsection{Soil preparation and characterization}

Air-dried soils were manually homogenized in a large polyethylene-lined box using shovels, rakes, and a small hand tiller. Large rocks and organic debris were removed during the homogenization process. The physical and chemical characteristics of the soils were determined using standard laboratory procedures. A complete list of the analytical methods used during this study can be found in the Appendix (Table A.1).

A modified digestion technique for metals analysis was used that included $8 \mathrm{~mL}$ nitric acid and $2 \mathrm{~mL}$ phosphoric acid instead of the traditional $10 \mathrm{~mL}$ nitric acid described in USEPA Method 200.7 in order to keep the tungsten oxides in solution during analysis (Griggs et al., 2009). A method detection limit (MDL) of $0.3 \mathrm{mg} \mathrm{kg}^{-1}$ was obtained for tungsten using inductively coupled plasma-atomic emission spectrometry (ICP-AES) following USEPA guidelines (USEPA, 1999). The corresponding practical quantization limit (PQL) for tungsten is $1.7 \mathrm{mg} \mathrm{kg}^{-1}$. USEPA Method 9081 was modified by using sodium sulfate for sodium acetate allowing the determination of CEC and AEC using the same sample extract.

Following soil homogenization, $200 \mathrm{~kg}$ of each test soil was transported to a test firing area where the soil was loaded into a catch box. Tungsten composite shots were loaded into canisters and fired into the test soils at a velocity of 1325 feet per second (fps) in preparation for the rainfall lysimeter study. The W-composite shots were fired into the soils to simulate possible temperature and stress effects on the shots during normal shooting activities.

The firing method used in this study did not simulate the actual firing conditions of the XM 1028 canister round munition, but the method used was more representative of environmental release of these projectiles than previous static studies (Dermatas et al. 2004; Ogunide et al. 2006). The exact muzzle velocity is not available for the XM 1028 canister round, but the estimated terminal velocity for the $\mathrm{W}$-composite shots from that round is $484 \mathrm{fps}$. It is expected that the shots from the XM 1028, with some combination of trajectory and distance between the firing point and point of impact, could result in a velocity of $1325 \mathrm{fps}$ at impact.

A total of $100 \mathrm{~W}$-composite shots were fired into each soil, to yield approximately $4000 \mathrm{mg} \mathrm{W}$ per $\mathrm{kg}$ soil or $800 \mathrm{~g} \mathrm{~W}$ in each amended soil. The fired-on soils were returned to ERDC-Environmental Laboratory for use in the mesoscale rainfall lysimeters.

\subsubsection{Rainfall lysimeter study for accelerated aging}

Rainfall lysimeter studies are extended leaching experiments, simulating the accelerated weathering of metals in soil. The current study was carried out according to the protocol described in Larson et al. (2004, 2005, 2007a) and yielded measurements of heavy metals in simulated leachate and runoff samples from three soil types that contained fired $\mathrm{W}$-composite shots. On average, $200 \mathrm{~kg}$ of soil was placed in three, $5-\mathrm{cm}$ increments over a sand layer (depth $7.62 \mathrm{~cm}$ ) in each lysimeter. The test soils were compacted to form a soil layer $15 \mathrm{~cm}$ deep. Soils fired on with $\mathrm{W}$-composite shots are the test soils and soils that were not fired on with the $\mathrm{W}$-composite shots are the control soils.

The lysimeter study simulated 1 year of aging of the $\mathrm{W}$-composite shots under field conditions. Over the course of the 16 week study, simulated rainfall was added to the lysimeter systems to replicate the total average annual rainfall $(128-\mathrm{cm}$ per year) at one of the ranges where site soils were collected. In order to simulate this amount of rainfall in 16 weeks, 8-cm per week, or 49.6$\mathrm{kg}$ of $\mathrm{RO}$ water ( $\mathrm{pH} 6$ ) per week, was applied to each lysimeter. Approximately 45 min was required to apply the total amount of simulated rainwater each week. Leachate and surface water runoff samples were collected from each lysimeter $24 \mathrm{~h}$ following the rainfall procedure. Runoff and leachate volumes were measured and $\mathrm{pH}$ and metal content were determined. Concentrations of metals in the leachate and runoff samples would indicate the potential for metal mobility of the $\mathrm{W}$ composite materials in the surface and groundwater. At the conclusion of the simulated aging study, the entire amount of soil in each lysimeter was removed. Representative soil samples were digested and analyzed for metal concentrations.

Intact composite shots were carefully removed from the lysimeter soils for SEM analysis. When the $\mathrm{W}$-composite shots were removed from the soil following the simulated aging study, a small amount of soil (crusts) adhered to the surface of the W-composite shots. The samples labeled Crust A were soil that was easily removed from the $\mathrm{W}$-composite shots and Crust B was soil that was more aggressively removed from the $\mathrm{W}$-composite shots. In order to collect Crust B samples, the $\mathrm{W}$-composite shots were placed in a $50-\mathrm{mL}$ nalgene tube and shaken vigorously for $5 \mathrm{~min}$. DDI water $(20-\mathrm{mL})$ was added to each tube and the solution was shaken for an additional $5 \mathrm{~min}$. The $\mathrm{W}$-composite shots were removed and the slurry was transferred to a tared container and dried at $95^{\circ} \mathrm{C}$ to produce a solid that was digested and analyzed for total metals concentrations. Given the small mass of the Crust B samples, all replicates from each treatment were added to one tared digestion vessel and the vessel was re-weighed to determine the weight of the Crust B sample. For this reason, there was only one replicate of Crust B for each soil type.

\subsubsection{Scanning electron microscopy (SEM)}

Micrograph images of the unfired, fired, and fired/aged W-composite shots were taken and spectra were recorded for each treatment using a LEO EVO 50 (Oxford Instruments, Oxfordshire, England) with an Oxford Electron Dispersion System (EDS) 
equipped with a secondary electron detector and a quartered backscatter detector. The software installed on this instrument was Inca Energy, version 18 . System settings were: magnification $1 \mathrm{k} \times$ to $15 \mathrm{k} \times$, beam energy was $20 \mathrm{kV}$, beam current was $100 \mu \mathrm{A}$, integration time was $40.6 \mathrm{~s}$, and the probe was $120 \mathrm{pA}$.

\section{Results and discussion}

\subsection{Soil characterization}

Using soils that exhibited variability in soil properties provided an opportunity to study W solubility and leaching in three distinct soil systems. Two soils, Silty Sand and Silt (loess), had no particles in the gravel-size range while the Sandy Clay consisted of over $2 \%$ gravel-size particles. The amount of fines in the test soils were $18 \%$ for Silty Sand, $88.9 \%$ for Sandy Clay, and $98.9 \%$ for silt. The percentage of sand was $18.1 \%, 8.4 \%$, and $1.1 \%$ for Silty Sand, Sandy Clay, and Silt respectively.

The soils exhibited a range in $\mathrm{pH}(5.1-8.7)$, CEC ( 4.5 to $11 \mathrm{meq}$ per $100 \mathrm{~g}$ soil), AEC (3.2-5.4 meq per $100 \mathrm{~g}$ soil), and TOC values $(<1-3.1 \%)$. Nutrient analysis results were similar for the three soils, which included: orthophosphate ( $\left.\leqslant 1.2 \mathrm{mg} \mathrm{kg}^{-1}\right)$, nitrogen present as ammonia (all $<1 \mathrm{mg} \mathrm{kg}^{-1}$ ), and nitrogen present as nitrites and nitrates (all $<1 \mathrm{mg} \mathrm{kg}^{-1}$ ).

\subsection{Lysimeter leachate}

Table 1 lists the total mass of dissolved $\mathrm{W}, \mathrm{Ni}$, and Fe detected in the leachate and surface runoff from the six rainfall lysimeters. When a single metal concentration in a triplicate sample was below the MDL $\left(0.010 \mathrm{mg} \mathrm{kg}^{-1}\right)$, a very conservative mass estimate was calculated using the volume of the sample and the MDL value. When all samples for a treatment yielded concentrations below the MDL, masses shown in Table 1 are preceded with a " $<$ ".

The leachate from the Silty Sand contained the highest total dissolved $\mathrm{W}$ mass $(6.28 \mathrm{mg})$ and the Silt samples contained the least $(2.12 \mathrm{mg})$. A lower dissolved $\mathrm{W}$ concentration in the leachate may indicate that W mobility was reduced in that soil system. However, a lower dissolved $\mathrm{W}$ concentration does not preclude $\mathrm{W}$ transport.

Higher dissolved W masses in the Silty Sand leachate samples may be attributed to two factors related to particle size distribution. First, the Silty Sand contains $81 \%$ sand. These coarser soil particles have been reported to shear off small particles from the $\mathrm{W}$ composite shots' surface during soil impact which translates into accelerated W dissolution (O'Connor et al., 2009). Second, W tends to be associated with the smallest particle size fraction (fines)
(Larson et al., 2007b) and Silty Sand has only 18\% fines compared to the higher percentages of fines in the other two soils. It might be expected, therefore, that less $\mathrm{W}$ would be associated with the Silty Sand soil and more W would transport as dissolved $\mathrm{W}$ in the leachate from the Silty Sand compared to the leachate from the other two soils.

Dissolved Ni concentrations were below the MDL in all leachate samples from all treatments. The dissolved Fe concentrations in the leachate samples were elevated (12-16\%) in all the test soils compared to the corresponding control soils, indicating Fe transport was similar for all three soil types. High initial Fe concentration in the soils may have contributed to the Fe mobility noted in the leachate and runoff samples.

\subsection{Lysimeter runoff water}

The runoff water samples from the Silt test soil contained the highest $\mathrm{W}$ mass among the samples from the three test soils (Table 1 ). This elevated $\mathrm{W}$ mass coincided with an elevated $\mathrm{W}$ soil concentration in the surface layer of the fine-grained soil, which was not seen in the other soil types. It was hypothesized that $\mathrm{W}$ was drawn up to the surface with the pore water, in a "wicking" process, similar to water being drawn up a capillary tube.

One of the soil constituents may be a factor in the "wicking" process. The Silt soil was analyzed using X-ray diffraction spectroscopy (Larson et al., 2007b) and the results indicated the presence of both expansive and non-expansive clays. X-ray backscatter results indicated aluminum $(\mathrm{Al})$ was on the surface of the $\mathrm{W}$-composite shot and $\mathrm{Al}$ is also indicative of clay particles.

As was seen in the leachate samples, dissolved Ni concentrations were below the MDL in all runoff samples from all treatments. The dissolved Fe concentrations in the runoff samples were slightly elevated in all the test soils compared to the corresponding control soils. This is similar to the dissolved Fe concentrations in the leachate samples.

\subsection{Lysimeter soil}

Lysimeter soils are separated into two classifications: the majority (bulk) of the soil removed from each lysimeter after the simulated aging and the soil removed from the immediate vicinity of the tungsten shots after simulated aging (crusts).

\subsubsection{Bulk soil concentrations}

No W was detected in the soils from any control cells. Tungsten concentrations in the test soils ranged from 1.3 to $5.3 \mathrm{mg} \mathrm{kg}^{-1}$,

Table 1

Total mass (mg) of dissolved W, Ni, and Fe in leachate and runoff samples from W composite and control soils.

\begin{tabular}{|c|c|c|c|c|c|c|}
\hline \multirow[t]{2}{*}{ Metal mass (mg) } & \multicolumn{6}{|l|}{ Soil type } \\
\hline & Sandy Clay control & Sandy Clay test & Silty Sand control & Silty Sand test & Silt control & Silt test \\
\hline \multicolumn{7}{|l|}{$W$} \\
\hline Runoff & $<2.0$ & 3.36 & $<2.0$ & $<2.0$ & $<2.0$ & 11.39 \\
\hline Leachate & $<2.0$ & 2.92 & $<2.0$ & 6.28 & $<2.0$ & 2.12 \\
\hline W total & $<4.0$ & 6.28 & $<4.0$ & 6.28 & $<4.0$ & 13.51 \\
\hline \multicolumn{7}{|l|}{$\mathrm{Ni}$} \\
\hline Runoff & $<2.0$ & $<2.0$ & $<2.0$ & $<2.0$ & $<2.0$ & $<2.0$ \\
\hline Leachate & $<2.0$ & $<2.0$ & $<2.0$ & $<2.0$ & $<2.0$ & $<2.0$ \\
\hline Ni total & $<4.0$ & $<4.0$ & $<4.0$ & $<4.0$ & $<4.0$ & $<4.0$ \\
\hline \multicolumn{7}{|l|}{$\mathrm{Fe}$} \\
\hline Runoff & 33.72 & 44.98 & 2.42 & 2.41 & 53.47 & 58.13 \\
\hline Leachate & 49.18 & 49.54 & 7.45 & 8.94 & 34.42 & 44.17 \\
\hline Fe total & 82.9 & 94.52 & 9.87 & 11.35 & 87.89 & 102.30 \\
\hline
\end{tabular}


with Silty Sand containing the highest concentration of W. Tungsten concentrations in the test soils therefore accounted for $\leqslant 0.1 \%$ of the total $\mathrm{W}$ added to the soil in each lysimeter after shot fragments were removed. The metal concentrations in the soils from the simulated aging study are presented in Supplemental material section.

No significant increase was noted in $\mathrm{Ni}$ or Fe concentrations from the test cells compared to the control cells in the Sandy Clay or Silty Sand soils. Nickel concentrations were below the laboratory reporting limit $\left(1.7 \mathrm{mg} \mathrm{kg}^{-1}\right)$ in both the Silty Sand control and test soils and Fe concentrations in the Silty Sand control and test soils were similar ( $8765 \mathrm{mg} \mathrm{kg}^{-1}$ compared to $8702 \mathrm{mg} \mathrm{kg}^{-1}$ ).

Nickel and Fe concentrations were slightly higher $(p=0.034$ and $p=0.006$, respectively) in the Silt control soil compared to the test soil, determined by the Mann-Whitney Rank Sum Test. Fe concentrations were $10067 \mathrm{mg} \mathrm{kg}^{-1}$ in the Silt control compared to $8498 \mathrm{mg} \mathrm{kg}^{-1}$ in the Silt test soil. Combined mass of soluble Fe (filtered) in the runoff and leachate from the Silt test soil were elevated compared to the Silt control which may explain this result. More Fe had transported out of the Silt test lysimeter than from the Silt control in the leachate or runoff water during the 16 -week test.

No Ni was detected ( $\mathrm{MDL}=0.05 \mathrm{mg} \mathrm{L}^{-1}$ ) in the leachate or runoff samples from either of the cells containing Silt soil, so Ni had not preferentially transported out of the Silt test lysimeter as Fe did. The differences in the $\mathrm{Ni}$ concentrations in the samples (11.7 compared to $10.1 \mathrm{mg} \mathrm{kg}^{-1}$ ) from the Silt soils following the lysimeter study may involve Ni solubility or differences in nickel sorption to soils fractions (Poulsen and Hansen, 2000; Li and Shuman, 1996; Ponizovskya et al., 2008).

\subsubsection{Crust soil concentrations}

The Crusts A and B samples, soil that had adhered to the Wcomposite shots after removal from the lysimeters, were digested and analyzed for metals content. Only $\mathrm{W}$ and Fe concentrations of the crust samples are presented in Table 2. The concentrations of the other metals were below detection limits.

Tungsten concentrations in the crust samples were elevated significantly compared to those of the bulk test soils. For example, the tungsten concentration for Crust A and B exposed to the Silty Sand was $1438 \mathrm{mg} \mathrm{kg}^{-1}$ and $19280 \mathrm{mg} \mathrm{kg}^{-1}$, respectively, compared to $5.29 \mathrm{mg} \mathrm{kg}^{-1}$ for the Silty Sand test soil. The $\mathrm{W}$ concentrations determined for Crust A samples ranged from 50\% to $4 \%$ of the W concentrations determined for the corresponding Crust B samples. This would indicate that tungsten leached from the surface of the W-composite shot but did not transport far during the simulated aging study, but remained very close to the W-composite shots.

Iron concentrations were also elevated in the Crusts A and B samples compared to the bulk test soils of all soil types following the simulated aging study. For example, Fe concentrations in Silty Sand Crust A samples were $40 \%$ higher and Crust B samples were $70 \%$ higher that the Fe concentrations in the bulk test soil. Iron concentrations in the Silt Crust A samples were 52\% higher than the Silt bulk test soil, but the Crust B sample Fe concentration was just slightly higher (12\%) than the Silt bulk test soil. The Crust B Fe con- centrations for Silty Sand and Sandy Clay were roughly twice those of the bulk test soils, indicating Fe dissolution from the W shots. Nickel concentrations in the crust samples were similar to the bulk test soil concentrations for each soil type.

The $\mathrm{W}$ concentrations in the Crusts A and B samples associated with each test soil were compared to each other to identify any effect caused by soil type. Crust A W concentrations were comparable for all test soils, but the Crust B W concentration for the Silt was elevated compared to the Crust B W concentrations associated with the other two soils. This may be attributed to the higher fines (smallest soil particle size) content of the Silt compared to the other two soil types. Iron concentrations were the same magnitude for Crusts A and B for all test soils, indicating that soil type had little effect on Fe dissolution. This may be attributed to the fact that the initial Fe concentrations in all the tested soils were high and a slight increase following Fe dissolution would be hard to differentiate.

\subsection{SEM}

\subsubsection{Unfired W-composite shot}

A micrograph of an unfired $\mathrm{W}$-composite shot, taken at a magnification of $1 \mathrm{k} \times$, is illustrated in Fig. 1 . Striations were noted on the surface of the unfired $\mathrm{W}$-composite shot that resembled a basket weave. Backscatter X-ray spectroscopy indicated that the surface consisted of iron, nickel, and tungsten, which are the chemical components of an untreated W-composite shot, plus carbon and oxygen. The carbon and oxygen were probably introduced through handling and processing procedures.

\subsubsection{Fired $W$-composite shot}

SEM images of W-composite shots fired into the three test soils are shown in Fig. 2.

The observed SEM results indicated that soil type did affect the surface of the fired W-composite shots. The extensive striation pattern visible on the unfired $\mathrm{W}$-composite shot (Fig. 1) is still visible on the shots fired into the Silt (Fig. 2), which consists mostly of fines (99\%). In contrast, the surface of the W-composite shots fired into the Silty Sand (Fig. 2), which has a significant sand fraction (82\%), appears smoother, with shallower striations.

The basket weave striations of the unfired shot were no longer evident after the W-composite shots were fired into Sandy Clay. Instead, they exhibited a "polished" appearance (Fig. 2), possibly due to a grinding effect caused by the combination of sand and gravel in that soil. The "polished" surfaces of the W-composite shots fired into Sandy Clay would indicate that some metal had been sheared off during impact with the soil as suggested by O'Connor et al. (2009).

$\mathrm{X}$-ray backscatter results indicated $\mathrm{W}, \mathrm{Fe}$, and $\mathrm{O}$ on the surface of all $\mathrm{W}$-composite shots fired into the three soil types, a result similar to the unfired W-composite shots. Sulfur and lead were also detected on the surface of the W-composite shots fired into the Sandy Clay and Silty Sand, potentially from the soils themselves. Backscatter data is listed in Supplemental material section. Table 3 displays the elements noted on the surface of the $\mathrm{W}$

Table 2

Iron and tungsten concentrations $\left(\mathrm{mg} \mathrm{kg}^{-1}\right)$ in Crusts A and B following the simulated aging study.

\begin{tabular}{|c|c|c|c|c|c|c|}
\hline \multirow[t]{3}{*}{ Treatment } & \multicolumn{6}{|c|}{ Metals concentration $\left(\mathrm{mg} \mathrm{kg}^{-1}\right)$ with one standard deviation } \\
\hline & \multicolumn{3}{|l|}{ Iron } & \multicolumn{3}{|l|}{ Tungsten } \\
\hline & Bulk test soil & Crust A & Crust B & Bulk test soil & Crust A & Crust B \\
\hline Silty Sand & $8702 \pm 670$ & $12,207 \pm 369$ & 14,960 & $5.3 \pm 2.7$ & $1438 \pm 82$ & 19,280 \\
\hline Sandy Clay & $15,092 \pm 1984$ & $19,567 \pm 2093$ & 29,070 & $1.3 \pm 2.7$ & $1066 \pm 143$ & 27,810 \\
\hline Silt & $8498 \pm 541$ & $13,057 \pm 159$ & 9550 & $3.0 \pm 3.1$ & $1447 \pm 23$ & 6956 \\
\hline
\end{tabular}




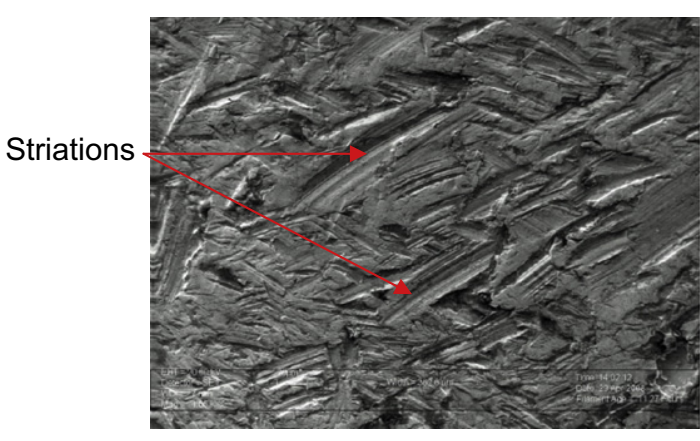

Fig. 1. SEM of unfired tungsten shot at $1 \mathrm{k} \times$ magnification.

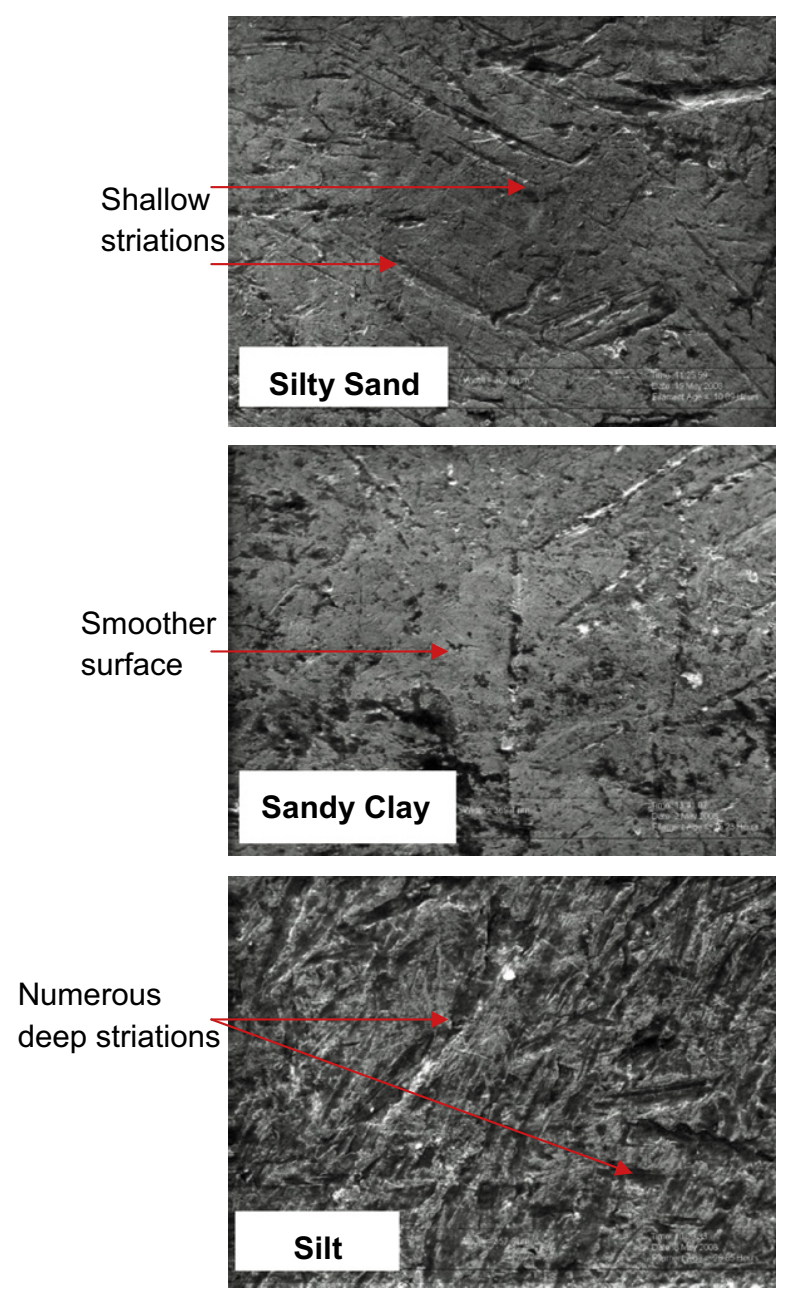

Fig. 2. Micrograph of $\mathrm{W}$-composite shot fired into three soil types at $1 \mathrm{k} \times$ magnification. Differences in appearance of the shot surface are representative of the effects produced by each soil type.

composite shots' surfaces following various treatments using backscatter X-ray spectroscopy.

\subsubsection{Fired and aged $W$-composite shot}

The micrographs (Fig. 3) of the W-composite shots from the lysimeter simulated aging study illustrate the differences in surface topography among the test treatments. "Crusted" samples were $\mathrm{W}$-composite shots that were covered with a thin layer of lysimeter soil. SEM analysis was also performed on shots with the soil crust removed (un-crusted). Micrographs of the crusted samples showed few distinctive surface features compared to the un-crusted samples but did yield information about soil composition in the layer closest to the weathered shots.

The white areas that appear on the micrographs are oxides that were formed during the simulated aging study. The oxides interfered with the conductivity of the $\mathrm{W}$ composite shot's surface, and therefore appear to be overexposed. Oxides indicate that oxidation of the $\mathrm{W}$ composite shot's surface had taken place during the simulated aging study. Oxides are visible on all three of the crusted samples, with the Silt samples exhibiting the greatest degree of oxidation. Silty Sand and Silt un-crusted samples also exhibited a sizable amount of oxides on the surface while the Sandy Clay un-crusted sample demonstrated almost no oxidation.

Other micrograph features also indicate that metal dissolution occurred during the simulated aging study. Plateaus and valleys are noted on the micrograph of the un-crusted Sandy Clay sample compared to the very smooth, almost polished, appearance of the surface of the unaged $\mathrm{W}$-composite shot fired into the Sandy Clay (Fig. 2). The surface of the composite shot taken from the uncrusted Silty Sand shows deep lines around rather large, irregularly shaped plateaus following simulated aging, which contrasts to the shallow lines on the surface of the $\mathrm{W}$-composite prior to the simulated aging study (Fig. 2). The deeper, exaggerated features on the surfaces of the aged samples compared to the surface of the fired, unaged samples indicate dissolution of the metal surface during the simulated aging study.

The difference in elemental analysis for various features on the un-crusted samples of W-composite shots aged in the three test soils illustrates the dissolution of metals during the simulated aging study (Table 4). Plateaus on the $\mathrm{W}$ composite surface of the Sandy Clay and Silty Sand samples generally had higher concentrations of $\mathrm{W}$ and less oxygen, a product of corrosion. Edges of a plateau had moderate concentrations of W. Valleys had the lowest concentration of $\mathrm{W}$, higher oxygen concentrations, and more soil constituents ( $\mathrm{Al}$ and $\mathrm{Si}$ ). These deeper features (valleys) indicate that surface corrosion had taken place. Backscatter X-ray spectroscopy results for $\mathrm{W}$-composite shots following all treatments (unfired, fired, and aged) are listed in Supplemental material section.

In contrast, few definable features were seen on the micrographs of the W-composite shots fired and aged in Silt. Elemental analysis results of the smooth and rough areas were comparable, which indicates minimal additional corrosion on the $\mathrm{W}$ composite shot's surface that was fired and aged in Silt.

\subsection{Effect of soil particle size on surface changes}

The type of soil the W-composite shots were fired into affected the surface of the shots and the leaching and mobility of the metals from the W-composite shots. The Sandy Clay contained the most gravel of the test soils and the surfaces of W-composite shots fired into the Sandy Clay were most affected by the firing impact. The surface of the W-composite shots fired into the Sandy Clay appeared polished after firing, having lost the basket weave appearance of the unfired shot. The micrograph of the un-crusted Sandy Clay sample appears to indicate that corrosion had taken place on the surface of these shots during the simulated aging study because distinct features and some oxides were noted on the shots' surface following that study. Tungsten was evidenced in bulk soil, leachate, and runoff following the simulated aging study and the $\mathrm{W}$ crust concentrations were higher than the crusts from the samples aged in the other two test soils.

The gravel in the Sandy Clay soil could create more friction between the shot and the soil and contribute to greater fragmentation upon impact. The small particles sheared from the surface of the $\mathrm{W}$-composite shots due to interaction with 
Table 3

Elements detected in backscatter X-ray spectroscopic analysis on the surface of $\mathrm{W}$ composite rounds from the simulated aging study.

\begin{tabular}{|c|c|c|c|c|c|c|c|c|c|c|c|c|}
\hline \multirow[t]{2}{*}{ Soil sample } & \multicolumn{12}{|c|}{ Elements } \\
\hline & W & $\mathrm{C}$ & $\mathrm{O}$ & $\mathrm{Al}$ & $\mathrm{Fe}$ & $\mathrm{Ni}$ & $\mathrm{Si}$ & $\mathrm{S}$ & $\mathrm{Pb}$ & $\mathrm{Ca}$ & $\mathrm{Sb}$ & Others \\
\hline Unfired & $\mathrm{X}$ & $\mathrm{X}$ & $\mathrm{X}$ & & $\mathrm{X}$ & $\mathrm{X}$ & & & & & & \\
\hline Sandy Clay fired & $\mathrm{X}$ & $\mathrm{X}$ & $\mathrm{X}$ & & $\mathrm{X}$ & & & $\mathrm{X}$ & $\mathrm{X}$ & & $\mathrm{X}$ & \\
\hline Sandy Clay un-crusted & $\mathrm{X}$ & $\mathrm{X}$ & $\mathrm{X}$ & $\mathrm{X}$ & $\mathrm{X}$ & $\mathrm{X}$ & & & $\mathrm{X}$ & $\mathrm{X}$ & & \\
\hline Sandy Clay crusted & $\mathrm{X}$ & $\mathrm{X}$ & $\mathrm{X}$ & $\mathrm{X}$ & $\mathrm{X}$ & & $\mathrm{X}$ & & & $\mathrm{X}$ & & $\mathrm{Mg}$ \\
\hline Silty Sand fired & $\mathrm{X}$ & $\mathrm{X}$ & $\mathrm{X}$ & $\mathrm{X}$ & $\mathrm{X}$ & $\mathrm{X}$ & & $\mathrm{X}$ & $\mathrm{X}$ & & $\mathrm{X}$ & \\
\hline Silty Sand crusted & $\mathrm{X}$ & & $\mathrm{X}$ & $\mathrm{X}$ & & & $\mathrm{X}$ & & & & & \\
\hline Silty Sand un-crusted & $\mathrm{X}$ & $\mathrm{X}$ & $\mathrm{X}$ & & $\mathrm{X}$ & & & & & & & \\
\hline Silt fired & $\mathrm{X}$ & & $\mathrm{X}$ & & $\mathrm{X}$ & & & & & & & \\
\hline Silt crusted & $\mathrm{X}$ & $\mathrm{X}$ & $\mathrm{X}$ & $\mathrm{X}$ & $\mathrm{X}$ & $\mathrm{X}$ & $\mathrm{X}$ & & & $\mathrm{X}$ & & $\mathrm{Mg}$ \\
\hline Silt un-crusted & $X$ & $X$ & $X$ & & & & & & & $\mathrm{X}$ & & $\mathrm{Sr}$ \\
\hline
\end{tabular}

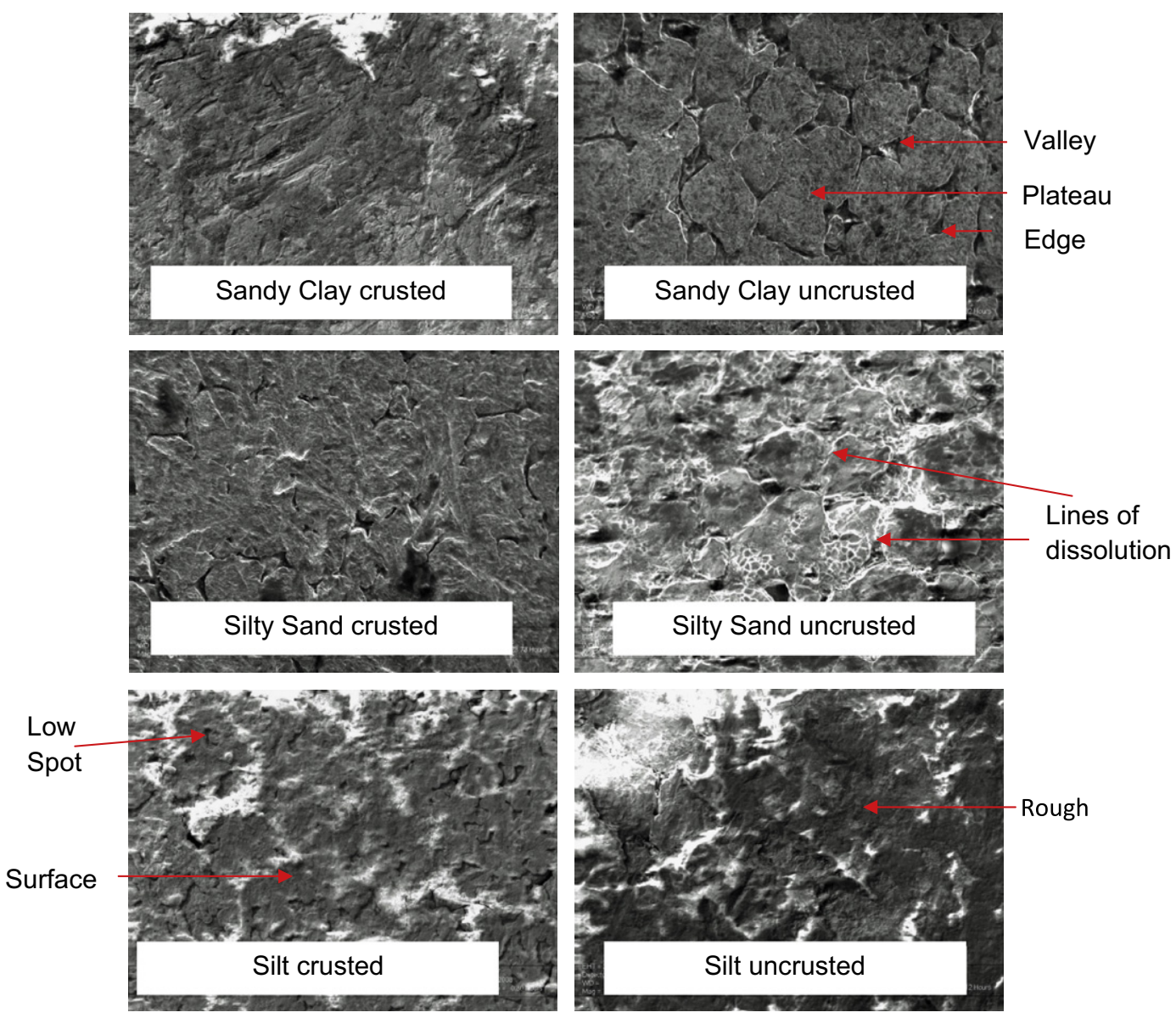

Fig. 3. Micrograph of W-composite shots after simulated aging in three soil types.

coarser soil particles have large surface areas and are more susceptible to dissolution or transport than metal components that are still intact on the shots' surface. Fragmentation of the W-composite shots would also expose more surface area than an intact shot.

The Silty Sand contained the most sand (81\%) and the least amount of fines (18\%) of the soils tested, but contained no gravel, and the affect of soil impact from Silty Sand was less on the W-composite shots than that of the Sandy Clay. Features on the W-composite shot after firing into the Silty Sand were smoother than the features on the unfired shots, but the surface did not appear polished. Oxides and definite features were noted on the micrographs of the $\mathrm{W}$ composite shot's surface after firing and aging in the Silty Sand, indicating corrosion of the surface.
The W leachate concentrations associated with the Silty Sand were elevated compared to the leachates associated with the other test soils, but no $\mathrm{W}$ was detected in the runoff samples associated with the Silty Sand. Particle size was probably also a factor in the W transport in this soil. The W bulk soil concentration in the Silty Sand was the highest of the three test soils following the simulated aging study, but the $\mathrm{W}$ concentration of all three soils were within one standard error of each other. Tungsten crust concentrations of the Silty Sand sample following simulated aging were moderate compared to the $\mathrm{W}$ crust concentrations associated with the other two test soils. Sand in the Silty Sand had a polishing affect on the W composite shot's surface, but less than the gravel in the Sandy Clay, which led to moderate corrosion of the W composite shot's surface following firing and aging in the Silty Sand. 
Table 4

Backscatter X-ray spectroscopy results for individual points on micrographs of W composite rounds' surface following the simulated aging study.

\begin{tabular}{|c|c|c|c|c|c|c|c|c|c|c|}
\hline \multirow[t]{2}{*}{ Soil samples } & \multicolumn{10}{|c|}{ Elements (\% of composition) } \\
\hline & W & $\mathrm{C}$ & 0 & $\mathrm{Al}$ & $\mathrm{Fe}$ & $\mathrm{Ni}$ & $\mathrm{Si}$ & $\mathrm{Pb}$ & $\mathrm{Ca}$ & Others \\
\hline \multicolumn{11}{|c|}{ Sandy Clay un-crusted } \\
\hline Plateau & 64 & 40 & 18 & - & - & - & - & - & - & \\
\hline Edge & 50 & - & 30 & 4 & 8 & 3 & - & 3 & 1 & \\
\hline \multicolumn{11}{|c|}{ Silty Sand un-crusted } \\
\hline Plateau & 71 & 3 & 22 & - & 1 & 1 & - & - & - & \\
\hline Edge & 55 & 4 & 32 & 3 & 2 & 0.8 & 3 & - & - & \\
\hline Valley & 33 & 3 & 44 & 7 & 3 & 2 & 7 & - & - & \\
\hline \multicolumn{11}{|l|}{ Silt un-crusted } \\
\hline Smooth & 61 & 6 & 20 & - & - & - & - & - & 13 & \\
\hline Rough & 53 & 10 & 21 & - & - & - & - & - & 13 & $\mathrm{Sr} 4 \%$ \\
\hline
\end{tabular}

The surfaces of the shots fired into Silt (98\% fines) were relatively unchanged as a result of impact with the Silt, and the least corrosion was evidenced on the W-composite shots fired and aged in this soil. The same basket weave pattern was visible on the $\mathrm{W}$ composite shot's surface after firing into the Silt as was on the unfired shot. The surface of the un-crusted Silt sample showed that relatively little corrosion on the shot's surface had occurred during the simulated aging study: no oxides and no definite features were visible. Metal analyses showed $\mathrm{W}$ concentrations in the crusts associated with the Silt were lower than the W concentrations associated with the other two soils. W concentrations in the runoff associated with Silt were higher than the W concentrations in the runoff samples associated with the other two test soils, but this was probably due to $\mathrm{W}$ wicking in that soil.

O'Connor et al. (2009) reported that fragmentation of $\mathrm{W}$ shots was more likely to occur when the shots were fired into coarsergrained soils. It would therefore be expected that soluble $\mathrm{W}$ concentrations (indicating $\mathrm{W}$ dissolution and mobility) would be elevated in the leachate from a coarser-grained soil (Sandy Clay) compared to the $\mathrm{W}$ concentrations in the leachate from a finergrained soil (Silt). The differences in the surface appearance of the fired W-composite shots may, therefore, indicate the environmental fate of the metal constituents of these shots.

Only one metallurgical formulation of $\mathrm{W}$-composite shot was used in this study. Ogunide et al. (2006) tested five metallurgical formulation using immersion and dissolution studies. They reported similar results when they immersed $\mathrm{W}$ composite materials in DI water for $15 \mathrm{~d}$ and wet/dry cycles with dilute $\mathrm{HCl}\left(10^{-4} \mathrm{M}\right)$. Ogunide et al. (2006) reported that the rate and manner of corro- sion from $\mathrm{W}$ composite materials is related to the constitution of the binder phase and the presence of iron in the formulation increases the susceptibility to galvanic corrosion. Further study is needed to determine if other $\mathrm{W}$ composite materials will yield similar dissolution results in actual soil systems to the results presented in this paper.

\section{Conclusions}

This paper focused on the metals associated with $\mathrm{W}$-composite shots after they are fired into soil during testing and training activities. Specifically, it evaluated the effect of soil particle size distribution on the surface of fired W-composite shots using soil types that are representative of Army installations where munitions containing the $\mathrm{W}$-composite shots have been, or will, be used. The current paper compliments a previous study (Ogunide et al. 2006) by looking at soil systems where W-composite shots were fired at 1325 fps into real site soils compared to static systems using flat disk of $\mathrm{W}$ composite materials in immersion and dissolution tests. The study yielded valuable data that provide previously undetermined deformation, corrosion, dissolution and mobility results associated with $\mathrm{W}$-composite shots.

The results from this study showed that fired W-composite shots exhibited slow, surface-based corrosion during a simulated aging study. Soil type, specifically particle size, was an important factor in metal abrasion. The surfaces of $\mathrm{W}$-composite shots fired into coarse-grained soil types were most affected by the firing impact. Smaller soil particles caused less mechanical strain on the Wcomposite shots as a result of the firing, which equated to less disruption of the shot's surface, less fragmentation, and less overall surface area on which corrosion could take place. Coarse-grain soils may increase the physical scoring and fragmentation of the $\mathrm{W}$-composite shots which may lead to slightly increased metal dissolution.

\section{Acknowledgments}

This work was funded by the Army Environmental Policy Institute. The sponsor did not assist with the actual research discussed in this article or the writing of this article.

\section{Appendix A}

See Table A1.

Table A1

Standard methods and instrumentation used for sample analysis.

\begin{tabular}{|c|c|c|}
\hline Test & Instrumentation & Standard method \\
\hline Specific gravity & Water pycnmeter & ASTM D-854 \\
\hline Particle size distribution & Hydrometer & ASTM D-422 ${ }^{\mathrm{a}}$ \\
\hline Soil & Classification & ASTM D-2487 \\
\hline Metals analysis & $\mathrm{ICP}^{-A E S^{\mathrm{b}}}$ & USEPA Method $200.7^{c}$ \\
\hline Cation exchange capacity (CEC) & ICP-AES & USEPA Method $9081^{\mathrm{d}}$ \\
\hline Anion exchange capacity (AEC) & ICP-AES & USEPA Method $9081^{\mathrm{d}}$ \\
\hline Total organic carbon (TOC) & Organic carbon analyzer & USEPA Method $415^{\mathrm{d}}$ \\
\hline Inorganic anions & Ion chromatography & USEPA Method $300^{\mathrm{d}}$ \\
\hline Soil pH & pH sensitive electrode & USEPA Method $1503^{d}$ \\
\hline $\begin{array}{l}\text { a American Society for Testing a } \\
\text { b ICP-AES - Inductively coupled } \\
\text { c United States Environmental P } \\
\text { d } \text { US Environmental Protection A }\end{array}$ & & \\
\hline
\end{tabular}




\section{Appendix B. Supplementary material}

Supplementary data associated with this article can be found, in the online version, at doi:10.1016/j.chemosphere.2011.02.035.

\section{References}

American Society for Testing and Materials (ASTM). 2007. Standard test methods D422, D854, and D 2487. ASTM International, West Conshohocken, PA.

Clausen, J., Taylor, S., Larson, S., Bednar, A., Ketterer, M., Griggs, C., Lambert, D., Hewitt, A., Ramsey, C., Bigl, S., Bailey, R. Perron, N., 2007. Fate and Transport of Tungsten at Camp Edwards Small Arms Ranges. Engineer Research and Development Center, Cold Regions Research and Engineering Laboratory, ERDC TR-07-5, Hanover, NH.

Davis, J.L., Larson, S.L., Felt, D.R., Nestler, C.C., Martin, W.A., Riggs, L., Valente, E.J., Bishop, G.R. 2007. Engineering Considerations for Hydroxide Treatment of Training Ranges. ERDC/EL TR-07-3, Engineer Research and Development Center, Vicksburg MS

Dermatas, D., Braida, W., Christodoulatos, C., Strigul, N., Panikov, N., Los, N., Larson, S. 2004. Solubility, Sorption and Soil Respiration Effects of Tungsten and Tungsten Alloys. Environ.Forensics 5, 5.

Felt, D.R., Bednar, A.J., Georgian, T., 2008. The effects of grinding methods on metals concentrations in soil. Talanta $77(1), 380$

Griggs, C., Larson, S., Gent, D., Nestler, C., O'Connor, G., Sheets, D., 2007. Evaluation of the Potential for Tungsten Migration from Small Arms Firing Ranges Toward Groundwater. Army Environmental Policy Institute, Arlington, VA.

Griggs, C., Larson, S., Nestler, C., Thompson, M., 2009. Coupling of oxygen and pH requirements for effective microwave-digestion of soils for tungsten analysis. Land Contam. Reclam. 17, 111.

Koutsospyros, A., Braida, W., Christodoulatos, C., Dermatas, D., Strigul, N., 2006. A review of tungsten: from environmental obscurity to scrutiny. J. Hazard. Mater. $136,1$.

Larson, S., Tardy, B., Beverly, M., Hearn, A., Thompson, M., Williams, G., 2004. Topical Application of Phosphate Amendments to Lead-contaminated Small Arms Firing Range Soils. ERDC/EL TR-04-15. Engineer Research and Development Center, Vicksburg, MS
Larson, S., Tardy, B., Rainwater, K., Tingle, J., 2005. Rainfall Lysimeter Evaluation of Leachability and Surface Transport of Heavy Metals from Six Soils with and without Phosphate Amendment. ERDC/EL TR-05-9. Engineer Research and Development Center, Vicksburg, MS.

Larson, S.L., Davis, J.L, Martin, W.A., Felt, D.R., Nestler, C.C., Brandon, D.L, Fabian, G. O'Connor, G., 2007a. Grenade Range Management using Lime for Metals Immobilization and Explosives Transformation. ERDC/EL TR-07-5. Engineer Research and Development Center, Vicksburg, MS

Larson, S., Weiss, C., Malone, P., Price, R.A., Batchelor, C, Capuano, C., Foote, C. Thompson, M., Powell, K, Beverly, M., Valentin, M., Williams, G., Trest, C. McGhee, C., Parson, H., 2007b. Small Arms Range use of Tungsten and Lead Bullet: Behavior of Metals in Range Soils. US Army Armament Research and Development Center, Heavy Metals Office Technical Report, Picatinny, NJ.

Li, Z., Shuman, L., 1996. Extractability of zinc, cadmium, and nickel in soils amended with EDTA. Soil Sci. 161, 226

Occupational Safety \& Health Administration (OSHA). 2009. Occupational Safety and Health Guidelines for Nickel, Soluble Compounds (as Ni). Occupational Safety \& Health Administration, Washington, DC. <http://www.osha.gov/SLTC healthguidelines/nickelsolublecompounds/recognition.html\#>

O'Connor, G., Larson, S., Griggs, C., Thompson, M., Nestler, C., 2009. Effect of soil type on tungsten leachability. Land Contam. Reclam. 17, 75.

Ogunide, A., Greenberg, B., Braida, W., Christodoulatos, C., Dermatis, D. (, 2006 Morphological characterization and spectroscopic studies of the corrosion behavior of tungsten heavy alloys. Corros. Sci. 48, 3281-3297.

Ponizovskya, A., Thakalia, S., Allena, H.E., Di Toroa, D.M., Ackermana, A.J., Metzlera, D.M., 2008. Nickel partitioning in acid soils at low moisture content. Geoderma $145(1-2), 69$.

Poulsen, I., Hansen, H., 2000. Soil sorption of nickel in the presence of citrate and arginine. Water, Air, Soil Pollut. 120, 249.

United States Environmental Protection Agency (USEPA), 1999. Test Methods for Evaluating Solid Waste. SW-846: Chemical/Physical Methods. Washington, DC

United States Environmental Protection Agency (USEPA), 2009. Lead in Paint, Dust and Soil. <http://www.epa.gov/lead/>

Winter, M., 2009. Nickel: the Essentials. WebElements: the Periodic Table on the web. The University of Sheffield and WebElements LTD, UK. <http:// www.webelements.com/nickel>

World Health Organization (WHO), 2003. Depleted Uranium. Fact Sheet 257. WHO Media Centre. <http://www.who.int/mediacentre/factsheets/fs257/en/> 


\section{Supplemental material}

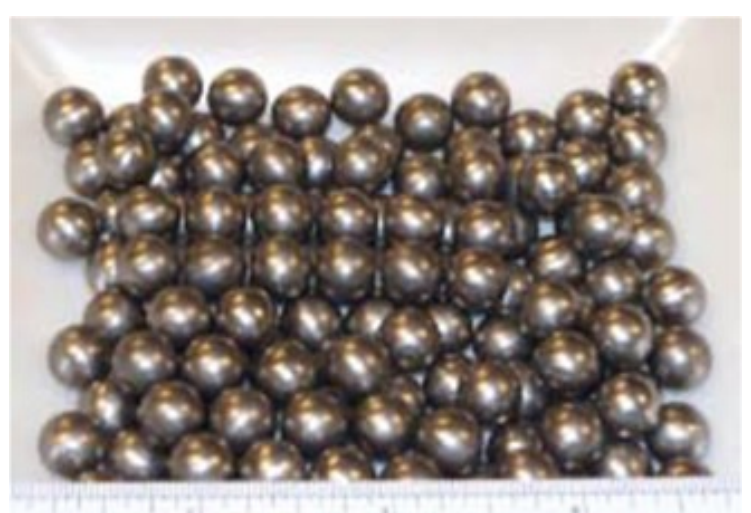

Photograph of typical W composite shots used in this study.

Average metals concentrations determined in control and $\mathrm{W}$-composite test lysimeter soils after simulated 1 year aging. $(n=3)$

\begin{tabular}{lcccccc}
\hline \multirow{2}{*}{$\begin{array}{l}\text { Metal mass } \\
(\mathbf{m g})\end{array}$} & $\begin{array}{c}\text { Sandy } \\
\text { Clay } \\
\text { Control }\end{array}$ & $\begin{array}{c}\text { Sandy } \\
\text { Clay } \\
\text { Test }\end{array}$ & $\begin{array}{c}\text { Silty Sand } \\
\text { Control }\end{array}$ & $\begin{array}{c}\text { Silty Sand } \\
\text { Test }\end{array}$ & $\begin{array}{c}\text { Silt } \\
\text { Control }\end{array}$ & $\begin{array}{c}\text { Silt } \\
\text { Test }\end{array}$ \\
\cline { 2 - 7 } $\mathbf{W}$ & $\mathrm{ND}$ & 1.3 & $\mathrm{ND}$ & 5.3 & $\mathrm{ND}$ & 3.0 \\
$\begin{array}{l}\text { average } \\
\begin{array}{l}\text { One standard } \\
\text { deviation }\end{array}\end{array}$ & & 2.7 & & 2.7 & & 3.1 \\
\hline $\begin{array}{l}\text { Ni } \\
\text { average }\end{array}$ & 19.6 & 19.4 & ND & ND & 11.7 & 10.1 \\
$\begin{array}{l}\text { One standard } \\
\text { deviation }\end{array}$ & 2.1 & 2.8 & & & 1.3 & 0.8 \\
\hline Fe & 15,435 & 15,092 & 8,765 & 8,702 & 10,067 & 8,498 \\
$\begin{array}{l}\text { average } \\
\begin{array}{l}\text { One standard } \\
\text { deviation }\end{array}\end{array}$ & 1,395 & 1,984 & 692 & 670 & 1,147 & 541 \\
\hline
\end{tabular}

$\mathrm{ND}$ - all replicates below the laboratory reporting limit $(1.7 \mathrm{mg} / \mathrm{kg})$ 


\section{BACKSCATTER X-RAY SPECTROSCOPY RESULTS}

\section{Backscatter $x$-ray spectroscopy data derived from an unfired W composite shot}

\begin{tabular}{lll}
\hline Un-Fired & W & Location Description \\
\hline Element & 100.00 & Polished \\
\hline Shot 1 & 100.00 & \\
Weight \% & 100.00 & Edge \\
Atomic \% & 100.00 & \\
\hline 1.2 & & \\
Weight \% & 100.00 & Polished Edge \\
Atomic \% & 100.00 & \\
\hline 1.3 & & \\
Weight \% & 100.00 & Pow Spot \\
Atomic\% $\%$ & 100.00 & \\
Shot 2 & & \\
Weight \% & 100.00 & \\
Atomic\% $\%$ & 100.00 & Pow Spot \\
\hline 2.2 & & \\
Weight \% & & \\
Atomic \% & & \\
\hline 2.3 & 100.00 & Polished \\
Weight \% & 100.00 & \\
Atomic \% & & \\
\hline Shot 3 & 100.00 & \\
Weight \% & 100.00 & \\
Atomic \% & 100.00 & \\
\hline 3.2 & 100.00 & \\
Weight \% & 100.00 & \\
Atomic \% & 100.00 & \\
\hline 3.3 & & \\
Weight \% & & \\
Atomic & & \\
\hline
\end{tabular}




\section{Backscatter $x$-ray spectroscopy data derived from $W$ composite shot fired into Sandy Clay}

\begin{tabular}{|c|c|c|c|c|c|c|c|c|}
\hline \multicolumn{9}{|c|}{ Sandy Clay Fired } \\
\hline Element & $\mathrm{C}$ & $\mathbf{O}$ & $\mathbf{W}$ & $\mathrm{Fe}$ & $\mathbf{S}$ & $\mathbf{S b}$ & $\mathbf{P b}$ & Location Description \\
\hline $\begin{array}{c}\text { Shot } 1 \\
\text { Weight \% } \\
\text { Atomic \% }\end{array}$ & $\begin{array}{c}3.83 \\
29.99\end{array}$ & $\begin{array}{c}3.86 \\
22.74\end{array}$ & $\begin{array}{l}92.31 \\
47.27\end{array}$ & & & & & Polished \\
\hline $\begin{array}{c}1.2 \\
\text { Weight \% } \\
\text { Atomic \% }\end{array}$ & $\begin{array}{c}4.90 \\
30.79\end{array}$ & $\begin{array}{c}6.48 \\
30.56\end{array}$ & $\begin{array}{l}86.35 \\
35.43\end{array}$ & & $\begin{array}{l}1.04 \\
2.45\end{array}$ & $\begin{array}{l}1.23 \\
0.76\end{array}$ & & Edge \\
\hline $\begin{array}{c}1.3 \\
\text { Weight \% } \\
\text { Atomic\% }\end{array}$ & $\begin{array}{c}4.62 \\
26.44\end{array}$ & $\begin{array}{c}9.24 \\
39.71\end{array}$ & $\begin{array}{l}85.23 \\
31.88 \\
\end{array}$ & & $\begin{array}{l}0.92 \\
1.97\end{array}$ & & & Polished Edge \\
\hline $\begin{array}{c}\text { Shot } 2 \\
\text { Weight } \% \\
\text { Atomic\% } \%\end{array}$ & $\begin{array}{c}5.67 \\
34.67\end{array}$ & $\begin{array}{c}6.22 \\
28.57\end{array}$ & $\begin{array}{l}87.30 \\
34.90\end{array}$ & & $\begin{array}{l}0.81 \\
1.86\end{array}$ & & & Low Spot \\
\hline $\begin{array}{c}2.2 \\
\text { Weight \% } \\
\text { Atomic \% }\end{array}$ & $\begin{array}{c}5.47 \\
31.57\end{array}$ & $\begin{array}{c}7.97 \\
34.55 \\
\end{array}$ & $\begin{array}{l}85.88 \\
32.40 \\
\end{array}$ & & $\begin{array}{l}0.69 \\
1.49\end{array}$ & & & Polished \\
\hline $\begin{array}{c}2.3 \\
\text { Weight \% } \\
\text { Atomic \% }\end{array}$ & $\begin{array}{c}4.29 \\
25.52\end{array}$ & $\begin{array}{c}8.98 \\
40.12\end{array}$ & $\begin{array}{l}85.99 \\
33.42\end{array}$ & $\begin{array}{l}0.73 \\
0.94\end{array}$ & & & & Low Spot \\
\hline $\begin{array}{c}\text { Shot } 3 \\
\text { Weight \% } \\
\text { Atomic \% }\end{array}$ & $\begin{array}{c}5.96 \\
35.50\end{array}$ & $\begin{array}{c}6.50 \\
29.04\end{array}$ & $\begin{array}{l}86.77 \\
33.74\end{array}$ & & $\begin{array}{l}0.77 \\
1.72\end{array}$ & & & Polished \\
\hline $\begin{array}{c}3.2 \\
\text { Weight \% } \\
\text { Atomic \% }\end{array}$ & $\begin{array}{c}4.42 \\
26.19\end{array}$ & $\begin{array}{c}9.06 \\
40.31\end{array}$ & $\begin{array}{l}86.52 \\
33.50\end{array}$ & & & & & Low Spot \\
\hline $\begin{array}{c}3.3 \\
\text { Weight \% } \\
\text { Atomic }\end{array}$ & $\begin{array}{c}3.86 \\
23.51\end{array}$ & $\begin{array}{c}9.03 \\
41.32\end{array}$ & $\begin{array}{l}83.46 \\
33.23\end{array}$ & $\begin{array}{l}0.68 \\
0.89\end{array}$ & & & $\begin{array}{l}2.97 \\
1.05\end{array}$ & Polished \\
\hline
\end{tabular}




\section{Backscatter x-ray spectroscopy data from W composite shot fired into Silty Sand}

\begin{tabular}{lllllllllll}
\hline Silty Sand & Fired & & & & & & & & & \\
\hline Element & $\mathbf{C}$ & $\mathbf{O}$ & $\mathbf{F e}$ & $\mathbf{N i}$ & $\mathbf{S b}$ & $\mathbf{W}$ & $\mathbf{P b}$ & $\mathbf{A l}$ & $\mathbf{S}$ & Location Description \\
\hline Shot 1 & & & & & & & & & & \\
Weight \% & 6.92 & 16.35 & 3.59 & 0.96 & 1.85 & 64.04 & 6.27 & & & Polished \\
Atomic \% & 27.80 & 49.30 & 3.10 & 0.79 & 0.73 & 16.80 & 1.46 & & & \\
\hline 1.2 & & & & & & & & & & \\
Weight \% & 8.56 & 19.14 & 5.85 & 1.00 & 3.43 & 59.23 & & 1.02 & 1.77 & Micro Scratch \\
Atomic \% & 28.81 & 48.35 & 4.23 & 0.69 & 1.14 & 13.02 & & 1.52 & 2.23 & \\
\hline 1.3 & & & & & & & & & & \\
Weight \% & 7.81 & 18.72 & 5.48 & & 3.06 & 63.72 & & 0.95 & 1.45 & Polished \\
Atomic\% & 27.56 & 49.59 & 4.16 & & 1.08 & 14.85 & & 1.52 & 1.94 & \\
\hline Shot 2 & & & & & & & & & & \\
Weight \% & 8.32 & 17.64 & 4.85 & & 3.06 & 63.72 & & 0.95 & 1.45 & Polished \\
Atomic\% & 29.68 & 47.22 & 3.72 & & 1.08 & 14.85 & & 1.52 & 1.94 & \\
\hline 2.2 & & & & & & & & & & \\
Weight \% & 7.48 & 18.16 & 5.76 & 0.88 & 3.69 & 54.79 & 7.61 & 0.88 & 0.75 & Polished \\
Atomic \% & 27.12 & 49.41 & 4.49 & 0.66 & 1.32 & 12.97 & 1.60 & 1.41 & 1.01 & \\
\hline 2.3 & & & & & & & & & & \\
Weight \% & 8.29 & 19.70 & 5.86 & 1.04 & 3.83 & 51.07 & 8.25 & 0.80 & 1.15 & Indention \\
Atomic \% & 28.07 & 50.07 & 4.27 & 0.72 & 1.28 & 11.30 & 1.62 & 1.21 & 1.46 & \\
\hline Shot 3 & & & & & & & & & & \\
Weight \% & 6.08 & 18.88 & 5.40 & & 2.42 & 59.89 & 7.33 & & & Polished \\
Atomic \% & 23.39 & 54.53 & 4.47 & & 0.92 & 15.05 & 1.64 & & & \\
\hline 3.2 & & & & & & & & & & Micro Scratch \\
Weight \% & 7.78 & 19.55 & 6.26 & & 3.96 & 52.90 & 7.93 & 0.86 & 0.76 & \\
Atomic \% & 27.05 & 50.99 & 4.68 & & 1.36 & 12.01 & 1.60 & 1.33 & 0.99 & \\
\hline 3.3 & & & & & & & & & & \\
Weight \% & 9.13 & 18.73 & 5.61 & 1.00 & 4.38 & 50.13 & 9.17 & 0.86 & 1.00 & Scratch \\
Atomic & 30.84 & 47.51 & 4.08 & 0.69 & 1.49 & 11.07 & 1.80 & 1.30 & 1.27 & \\
\hline
\end{tabular}




\section{Backscatter $x$-ray spectroscopy data derived from W composite shot fired into Silt}

\begin{tabular}{|c|c|c|c|c|}
\hline Silt Fired & & & & \\
\hline Element & $\mathbf{O}$ & $\mathbf{F e}$ & $\mathbf{W}$ & Location Description \\
\hline $\begin{array}{l}\text { Shot } 1 \\
\text { Weight \% } \\
\text { Atomic \% }\end{array}$ & $\begin{array}{l}8.58 \\
50.38\end{array}$ & $\begin{array}{l}2.46 \\
4.15\end{array}$ & $\begin{array}{l}88.96 \\
45.48\end{array}$ & Rough \\
\hline $\begin{array}{l}1.2 \\
\text { Weight } \% \\
\text { Atomic } \%\end{array}$ & $\begin{array}{l}6.76 \\
45.46\end{array}$ & & $\begin{array}{l}93.24 \\
54.54\end{array}$ & Rough \\
\hline $\begin{array}{l}\text { Weight \% } \\
\text { Atomic\% }\end{array}$ & $\begin{array}{l}6.63 \\
44.92 \\
\end{array}$ & & $\begin{array}{l}93.37 \\
55.08 \\
\end{array}$ & Smooth \\
\hline $\begin{array}{l}\text { Shot } 2 \\
\text { Weight \% } \\
\text { Atomic\% }\end{array}$ & $\begin{array}{l}6.55 \\
44.61\end{array}$ & & $\begin{array}{l}93.45 \\
55.39\end{array}$ & Rough \\
\hline $\begin{array}{l}2.2 \\
\text { Weight \% } \\
\text { Atomic \% }\end{array}$ & $\begin{array}{l}6.48 \\
44.32\end{array}$ & & $\begin{array}{l}93.52 \\
55.68\end{array}$ & Rough \\
\hline $\begin{array}{l}2.3 \\
\text { Weight \% } \\
\text { Atomic \% }\end{array}$ & $\begin{array}{l}5.68 \\
40.91\end{array}$ & & $\begin{array}{l}94.32 \\
59.09\end{array}$ & Smooth \\
\hline $\begin{array}{l}\text { Shot } 3 \\
\text { Weight \% } \\
\text { Atomic \% }\end{array}$ & $\begin{array}{l}6.30 \\
43.57\end{array}$ & & $\begin{array}{l}93.70 \\
56.43\end{array}$ & Rough \\
\hline $\begin{array}{l}3.2 \\
\text { Weight \% } \\
\text { Atomic \% }\end{array}$ & $\begin{array}{l}5.59 \\
40.49\end{array}$ & & $\begin{array}{l}94.41 \\
59.51\end{array}$ & Rough \\
\hline $\begin{array}{l}3.3 \\
\text { Weight \% } \\
\text { Atomic }\end{array}$ & $\begin{array}{l}5.95 \\
42.10\end{array}$ & & $\begin{array}{l}94.05 \\
57.90\end{array}$ & Rough \\
\hline
\end{tabular}




\begin{tabular}{|c|c|c|c|c|c|c|c|c|c|c|c|}
\hline \multicolumn{12}{|c|}{ Sandy Clay Un-Crusted } \\
\hline Element & Al & $\mathbf{C a}$ & $\mathrm{C}$ & $\mathbf{O}$ & $\mathbf{W}$ & $\mathbf{F e}$ & $\mathbf{N i}$ & Ta & $\mathbf{R e}$ & $\mathbf{P b}$ & $\begin{array}{l}\text { Location } \\
\text { Description }\end{array}$ \\
\hline $\begin{array}{l}\text { Shot } 1 \\
\text { Weight \% } \\
\text { Atomic \% }\end{array}$ & & $\begin{array}{l}5.37 \\
5.01\end{array}$ & $\begin{array}{l}12.93 \\
40.27\end{array}$ & $\begin{array}{l}17.85 \\
41.73\end{array}$ & $\begin{array}{l}63.85 \\
12.99\end{array}$ & & & & & & Plateau \\
\hline $\begin{array}{l}1,2 \\
\text { Weight } \% \\
\text { Atomic } \%\end{array}$ & $\begin{array}{l}1.70 \\
2.51\end{array}$ & $\begin{array}{l}0.92 \\
0.92\end{array}$ & $\begin{array}{l}6.11 \\
20.21\end{array}$ & $\begin{array}{l}23.82 \\
59.13\end{array}$ & $\begin{array}{l}59.85 \\
12.93\end{array}$ & $\begin{array}{l}3.66 \\
2.61\end{array}$ & $\begin{array}{l}1.96 \\
1.32\end{array}$ & & & $\begin{array}{l}1.98 \\
0.38\end{array}$ & Plateau \\
\hline $\begin{array}{l}1,3 \\
\text { Weight } \% \\
\text { Atomic\% }\end{array}$ & $\begin{array}{l}1.13 \\
1.86\end{array}$ & $\begin{array}{l}4.36 \\
4.83\end{array}$ & $\begin{array}{l}3.75 \\
13.86\end{array}$ & $\begin{array}{l}21.82 \\
60.55\end{array}$ & $\begin{array}{l}61.13 \\
14.76\end{array}$ & $\begin{array}{l}2.53 \\
2.01\end{array}$ & $\begin{array}{l}1.62 \\
1.22\end{array}$ & & & & Plateau \\
\hline $\begin{array}{l}\text { Shot } 2 \\
\text { Weight \% } \\
\text { Atomic } \%\end{array}$ & $\begin{array}{l}1.24 \\
2.59 \\
\end{array}$ & $\begin{array}{l}1.53 \\
2.14 \\
\end{array}$ & & $\begin{array}{l}19.46 \\
68316\end{array}$ & $\begin{array}{l}72.67 \\
22.15 \\
\end{array}$ & $\begin{array}{l}2.09 \\
2.10\end{array}$ & $\begin{array}{l}3.00 \\
2.86\end{array}$ & & & & Plateau \\
\hline $\begin{array}{l}2,2 \\
\text { Weight } \% \\
\text { Atomic } \%\end{array}$ & $\begin{array}{l}4.59 \\
6.68 \\
\end{array}$ & $\begin{array}{l}1.44 \\
1.42 \\
\end{array}$ & & $\begin{array}{l}29.71 \\
72.92\end{array}$ & $\begin{array}{l}45.43 \\
9.70\end{array}$ & $\begin{array}{l}7.63 \\
5.36\end{array}$ & $\begin{array}{l}3.45 \\
2.31\end{array}$ & $\begin{array}{l}5.19 \\
1.13\end{array}$ & & $\begin{array}{l}2.56 \\
0.49\end{array}$ & Edge \\
\hline $\begin{array}{l}2,3 \\
\text { Weight } \% \\
\text { Atomic } \%\end{array}$ & $\begin{array}{l}2.58 \\
4.58\end{array}$ & $\begin{array}{l}1.39 \\
1.66\end{array}$ & & $\begin{array}{l}22.90 \\
68.42\end{array}$ & $\begin{array}{l}60.49 \\
15.73\end{array}$ & $\begin{array}{l}8.32 \\
7.12\end{array}$ & $\begin{array}{l}2.57 \\
2.10\end{array}$ & & & $\begin{array}{l}1.75 \\
0.40\end{array}$ & Edge \\
\hline $\begin{array}{l}\text { Shot } 3 \\
\text { Weight \% } \\
\text { Atomic \% }\end{array}$ & & $\begin{array}{l}9.38 \\
9.18\end{array}$ & $\begin{array}{l}2.91 \\
9.49\end{array}$ & $\begin{array}{l}27.41 \\
67.17\end{array}$ & $\begin{array}{l}54.34 \\
11.59\end{array}$ & $\begin{array}{l}1.61 \\
1.13\end{array}$ & $\begin{array}{l}1.15 \\
0.77\end{array}$ & & $\begin{array}{l}3.20 \\
0.67\end{array}$ & & Plateau \\
\hline $\begin{array}{l}3,2 \\
\text { Weight \% } \\
\text { Atomic } \%\end{array}$ & & $\begin{array}{l}7.01 \\
9.02\end{array}$ & & $\begin{array}{l}22.05 \\
71.08\end{array}$ & $\begin{array}{l}71.11 \\
19.95\end{array}$ & & & & & & Plateau \\
\hline $\begin{array}{l}3,3 \\
\text { Weight \% } \\
\text { Atomic }\end{array}$ & $\begin{array}{l}4.30 \\
7.60\end{array}$ & $\begin{array}{l}1.38 \\
1.65\end{array}$ & & $\begin{array}{l}22.82 \\
68.07\end{array}$ & $\begin{array}{l}56.77 \\
14.73\end{array}$ & $\begin{array}{l}7.07 \\
6.04\end{array}$ & & $\begin{array}{l}4.44 \\
1.17\end{array}$ & & $\begin{array}{l}3.21 \\
0.74\end{array}$ & Plateau \\
\hline
\end{tabular}




\section{Backscatter $\mathrm{x}$-ray spectroscopy data derived from a $\mathrm{W}$ composite shot fired and aged in Sandy Clay (crusted).}

\begin{tabular}{lllllllllll}
\hline Sandy Clay Crusted & & & & & & & \\
\hline Element & Al & Ca & C & O & W & Fe & Si & K & Mg & Location Description \\
\hline Shot 1 & & & & & & & & & & Plateau \\
Weight \% & 2.21 & 1.55 & 5.39 & 19.43 & 69.05 & & 2.45 & & \\
Atomic \% & 3.66 & 1.73 & 20.01 & 53.94 & 16.76 & & & & \\
\hline 1,2 & & & & & & & & & \\
Weight \% & 4.11 & 1.29 & 7.71 & 38.28 & 40.17 & & 7.17 & 1.27 & Edge \\
Atomic \% & 4.09 & 0.87 & 17.22 & 64.23 & 5.87 & & 6.86 & 0.87 & \\
\hline 1,3 & & & & & & & & & \\
Weight \% & 4.43 & 1.41 & 4.84 & 38.31 & 40.87 & 1.94 & 6.61 & 1.60 & Plateau \\
Atomic\% & 4.65 & 1.00 & 11.42 & 67.83 & 6.30 & 0.98 & 6.66 & 1.16 & \\
\hline Shot 2 & & & & & & & & & \\
Weight \% & 2.75 & 1.90 & 6.97 & 23.96 & 60.71 & & 3.71 & & Plateau \\
Atomic\% & 3.78 & 1.77 & 21.57 & 55.69 & 12.28 & & 4.92 & & \\
\hline 2,2 & & & & & & & & & \\
Weight \% & 4.81 & & 4.76 & 40.28 & 39.14 & 2.71 & 7.14 & 1.16 & Plateau \\
Atomic \% & 4.90 & & 10.90 & 69.22 & 5.85 & 1.33 & 6.99 & 0.82 & \\
\hline 2,3 & & & & & & & & & & \\
Weight \% & 0.00 & 0.00 & 0.00 & 0.00 & 0.00 & 0.00 & 0.00 & 0.00 & Plateau \\
Atomic \% & 0.00 & 0.00 & 0.00 & 0.00 & 0.00 & 0.00 & 0.00 & 0.00 & \\
\hline Shot 3 & & & & & & & & & & \\
Weight \% & 3.08 & 1.42 & 6.82 & 29.72 & 48.72 & 3.36 & 5.56 & 1.32 & Valley \\
Atomic \% & 3.65 & 1.13 & 18.12 & 59.31 & 8.46 & 1.92 & 6.32 & 1.08 & \\
\hline 3,2 & & & & & & & & & & \\
Weight \% & 4.42 & 1.21 & 7.12 & 39.79 & 36.23 & 2.27 & 6.35 & 1.81 & 0.79 & Plateau \\
Atomic \% & 4.29 & 0.79 & 15.53 & 65.17 & 5.16 & 1.06 & 5.93 & 1.21 & 0.85 & \\
\hline 3,3 & & & & & & & & & \\
Weight \% & 4.08 & 1.32 & & 36.06 & 47.99 & 2.37 & 6.65 & 1.54 & Plateau \\
Atomic & 5.01 & 1.09 & & 74.7 & 8.65 & 1.40 & 7.84 & 1.30 & & \\
\hline
\end{tabular}




\section{Backscatter $\mathrm{x}$-ray spectroscopy data derived from a $\mathrm{W}$ composite shot fired and aged in Silty Sand (crusted)}

\begin{tabular}{|c|c|c|c|c|c|}
\hline \multicolumn{6}{|c|}{ Silty Sand Crusted } \\
\hline Element & $\mathbf{W}$ & $\mathbf{O}$ & Al & $\mathbf{S i}$ & $\begin{array}{l}\text { Location } \\
\text { Description }\end{array}$ \\
\hline $\begin{array}{l}\text { Shot } 1 \\
\text { Weight \% } \\
\text { Atomic \% }\end{array}$ & & & & & Edge or Plateau \\
\hline $\begin{array}{l}1,2 \\
\text { Weight \% } \\
\text { Atomic \% }\end{array}$ & $\begin{array}{l}87.37 \\
62.42 \\
\end{array}$ & $\begin{array}{l}12.63 \\
62.42 \\
\end{array}$ & & & Plateau \\
\hline $\begin{array}{l}1,3 \\
\text { Weight } \% \\
\text { Atomic\% }\end{array}$ & $\begin{array}{l}72.45 \\
20.10\end{array}$ & $\begin{array}{l}21.61 \\
68.89 \\
\end{array}$ & $\begin{array}{l}2.91 \\
5.49 \\
\end{array}$ & $\begin{array}{l}3.03 \\
5.51\end{array}$ & $\begin{array}{l}\text { Plateau } \\
* \text { attached soil }\end{array}$ \\
\hline $\begin{array}{l}\text { Shot } 2 \\
\text { Weight \% } \\
\text { Atomic\% }\end{array}$ & $\begin{array}{l}100.00 \\
100.00 \\
\end{array}$ & & & & Deep Valley \\
\hline $\begin{array}{l}2,2 \\
\text { Weight \% } \\
\text { Atomic \% }\end{array}$ & $\begin{array}{l}100.00 \\
100.00 \\
\end{array}$ & & & & Low Valley \\
\hline $\begin{array}{l}2,3 \\
\text { Weight \% } \\
\text { Atomic \% }\end{array}$ & $\begin{array}{l}100.00 \\
100.00\end{array}$ & & & & Low Valley \\
\hline $\begin{array}{l}\text { Shot } 3 \\
\text { Weight \% } \\
\text { Atomic \% }\end{array}$ & $\begin{array}{l}25.59 \\
3.24 \\
\end{array}$ & $\begin{array}{l}55.47 \\
80.75 \\
\end{array}$ & $\begin{array}{l}8.72 \\
7.53 \\
\end{array}$ & $\begin{array}{l}10.22 \\
8.48 \\
\end{array}$ & Valley \\
\hline $\begin{array}{l}3,2 \\
\text { Weight \% } \\
\text { Atomic \% }\end{array}$ & & $\begin{array}{l}65.35 \\
76.46\end{array}$ & $\begin{array}{l}16.19 \\
11.24\end{array}$ & $\begin{array}{l}18.45 \\
12.30\end{array}$ & $\begin{array}{l}\text { Valley } \\
\text { *attached soil }\end{array}$ \\
\hline $\begin{array}{l}3,3 \\
\text { Weight \% } \\
\text { Atomic }\end{array}$ & $\begin{array}{l}100.00 \\
100.00\end{array}$ & & & & Plateau \\
\hline
\end{tabular}




\section{Backscatter $x$-ray spectroscopy data derived from a $\mathrm{W}$ composite shot fired and aged in Silty Sand (uncrusted).}

\begin{tabular}{|c|c|c|c|c|c|c|c|c|c|}
\hline \multicolumn{10}{|c|}{ Silty Sand Un-Crusted } \\
\hline Element & $\mathrm{C}$ & $\mathbf{O}$ & $\mathrm{Fe}$ & $\mathbf{W}$ & Al & $\mathbf{S i}$ & $\mathbf{N i}$ & $\mathrm{Br}$ & $\begin{array}{l}\text { Location } \\
\text { Description }\end{array}$ \\
\hline $\begin{array}{l}\text { Shot } 1 \\
\text { Weight \% } \\
\text { Atomic \% }\end{array}$ & $\begin{array}{l}2.62 \\
5.78\end{array}$ & $\begin{array}{l}44.23 \\
73.13\end{array}$ & $\begin{array}{l}3.29 \\
1.56\end{array}$ & $\begin{array}{l}33.38 \\
4.80\end{array}$ & $\begin{array}{l}7.29 \\
7.15\end{array}$ & $\begin{array}{l}7.01 \\
6.60\end{array}$ & $\begin{array}{l}2.17 \\
0.98\end{array}$ & & Valley \\
\hline $\begin{array}{l}1,2 \\
\text { Weight } \% \\
\text { Atomic } \%\end{array}$ & & $\begin{array}{l}15.52 \\
67.52\end{array}$ & $\begin{array}{l}0.56 \\
0.70\end{array}$ & $\begin{array}{l}83.92 \\
31.78\end{array}$ & & & & & Plateau \\
\hline $\begin{array}{l}1,3 \\
\text { Weight } \% \\
\text { Atomic\% }\end{array}$ & $\begin{array}{l}8.06 \\
35.55\end{array}$ & $\begin{array}{l}12.42 \\
41.11\end{array}$ & $\begin{array}{l}0.68 \\
0.64\end{array}$ & $\begin{array}{l}78.84 \\
22.70\end{array}$ & & & & & Plateau \\
\hline $\begin{array}{l}\text { Shot } 2 \\
\text { Weight \% } \\
\text { Atomic\% }\end{array}$ & $\begin{array}{l}4.44 \\
12.65\end{array}$ & $\begin{array}{l}31.89 \\
68.23\end{array}$ & $\begin{array}{l}2.43 \\
1.49\end{array}$ & $\begin{array}{l}54.87 \\
10.22\end{array}$ & $\begin{array}{l}2.93 \\
3.72\end{array}$ & $\begin{array}{l}2.65 \\
3.23\end{array}$ & $\begin{array}{l}0.80 \\
0.47\end{array}$ & & Edge \\
\hline $\begin{array}{l}2,2 \\
\text { Weight } \% \\
\text { Atomic } \%\end{array}$ & $\begin{array}{l}3.46 \\
13.54\end{array}$ & $\begin{array}{l}22.48 \\
66.05 \\
\end{array}$ & $\begin{array}{l}1.10 \\
0.92 \\
\end{array}$ & $\begin{array}{l}71.42 \\
18.26\end{array}$ & & & $\begin{array}{l}1.54 \\
1.23 \\
\end{array}$ & & Plateau \\
\hline $\begin{array}{l}2,3 \\
\text { Weight } \% \\
\text { Atomic \% }\end{array}$ & $\begin{array}{l}48.86 \\
73.58\end{array}$ & & $\begin{array}{l}4.59 \\
1.98\end{array}$ & $\begin{array}{l}21.90 \\
2.87\end{array}$ & $\begin{array}{l}12.09 \\
10.79\end{array}$ & $\begin{array}{l}12.57 \\
10.78\end{array}$ & & & Pit \\
\hline $\begin{array}{l}\text { Shot } 3 \\
\text { Weight \% } \\
\text { Atomic \% }\end{array}$ & $\begin{array}{l}3.32 \\
7.91\end{array}$ & $\begin{array}{l}39.28 \\
70.24\end{array}$ & $\begin{array}{l}3.63 \\
1.86\end{array}$ & $\begin{array}{l}39.57 \\
6.16\end{array}$ & $\begin{array}{l}6.57 \\
6.97\end{array}$ & $\begin{array}{l}5.91 \\
6.02\end{array}$ & $\begin{array}{l}1.72 \\
0.84\end{array}$ & & Edge \\
\hline $\begin{array}{l}3,2 \\
\text { Weight } \% \\
\text { Atomic } \%\end{array}$ & $\begin{array}{l}2.05 \\
7.24\end{array}$ & $\begin{array}{l}27.75 \\
73.47\end{array}$ & $\begin{array}{l}2.82 \\
2.14\end{array}$ & $\begin{array}{l}62.38 \\
14.37\end{array}$ & & & $\begin{array}{l}0.72 \\
0.52\end{array}$ & $\begin{array}{l}4.27 \\
2.27\end{array}$ & Valley \\
\hline $\begin{array}{l}3,3 \\
\text { Weight \% } \\
\text { Atomic }\end{array}$ & & $\begin{array}{l}28.96 \\
64.37\end{array}$ & $\begin{array}{l}9.85 \\
6.27\end{array}$ & $\begin{array}{l}40.74 \\
7.88\end{array}$ & $\begin{array}{l}6.84 \\
9.02\end{array}$ & $\begin{array}{l}6.35 \\
8.05\end{array}$ & $\begin{array}{l}7.25 \\
4.39\end{array}$ & & Plateau \\
\hline
\end{tabular}




\section{Backscatter $\mathrm{x}$-ray spectroscopy data derived from a $\mathrm{W}$ composite shot fired and aged in Silt (crusted)}

\begin{tabular}{|c|c|c|c|c|c|c|c|c|c|c|}
\hline \multicolumn{11}{|c|}{ Silt Crusted } \\
\hline Element & $\mathbf{O}$ & $\mathbf{C a}$ & $\mathbf{F e}$ & $\mathbf{W}$ & Si & $\mathbf{A l}$ & $\mathbf{C}$ & Mg & $\mathbf{N i}$ & Location Description \\
\hline $\begin{array}{l}\text { Shot } 1 \\
\text { Weight \% } \\
\text { Atomic } \\
\%\end{array}$ & $\begin{array}{l}28.42 \\
74.24\end{array}$ & $\begin{array}{l}10.97 \\
11.44\end{array}$ & $\begin{array}{l}1.03 \\
0.77\end{array}$ & $\begin{array}{l}59.57 \\
13.54\end{array}$ & & & & & & Low Spot \\
\hline $\begin{array}{l}1,2 \\
\text { Weight \% } \\
\text { Atomic } \\
\%\end{array}$ & $\begin{array}{l}27.98 \\
72.57\end{array}$ & $\begin{array}{l}11.55 \\
11.96\end{array}$ & & $\begin{array}{l}59.02 \\
13.32\end{array}$ & $\begin{array}{l}1.45 \\
2.15\end{array}$ & & & & & Surface \\
\hline $\begin{array}{l}1,3 \\
\text { Weight } \% \\
\text { Atomic } \%\end{array}$ & $\begin{array}{l}46.17 \\
73.71 \\
\end{array}$ & $\begin{array}{l}1.95 \\
1.25 \\
\end{array}$ & $\begin{array}{l}7.05 \\
3.23 \\
\end{array}$ & $\begin{array}{l}25.01 \\
3.47 \\
\end{array}$ & $\begin{array}{l}11.02 \\
10.02 \\
\end{array}$ & $\begin{array}{l}8.79 \\
8.32 \\
\end{array}$ & & & & Low Spot \\
\hline $\begin{array}{l}\text { Shot } 2 \\
\text { Weight } \% \\
\text { Atomic } \%\end{array}$ & $\begin{array}{l}31.57 \\
63.15 \\
\end{array}$ & $\begin{array}{l}5.44 \\
4.35 \\
\end{array}$ & $\begin{array}{l}12.06 \\
6.91 \\
\end{array}$ & $\begin{array}{l}37.53 \\
6.53 \\
\end{array}$ & $\begin{array}{l}5.39 \\
6.15 \\
\end{array}$ & $\begin{array}{l}2.65 \\
3.14 \\
\end{array}$ & $\begin{array}{l}2.89 \\
7.70 \\
\end{array}$ & $\begin{array}{l}0.95 \\
1.26 \\
\end{array}$ & $\begin{array}{l}1.52 \\
0.83 \\
\end{array}$ & Attached Soil \\
\hline $\begin{array}{l}2,2 \\
\text { Weight \% } \\
\text { Atomic } \\
\%\end{array}$ & $\begin{array}{l}28.81 \\
68.69\end{array}$ & $\begin{array}{l}8.29 \\
7.89\end{array}$ & $\begin{array}{l}9.86 \\
6.74\end{array}$ & $\begin{array}{l}48.20 \\
10.00\end{array}$ & $\begin{array}{l}2.91 \\
3.95\end{array}$ & $\begin{array}{l}1.93 \\
2.73\end{array}$ & & & & Attached Soil \\
\hline $\begin{array}{l}2,3 \\
\text { Weight } \% \\
\text { Atomic } \\
\% \\
\end{array}$ & $\begin{array}{l}44.62 \\
64.95\end{array}$ & $\begin{array}{l}3.49 \\
2.03\end{array}$ & $\begin{array}{l}7.90 \\
3.29\end{array}$ & $\begin{array}{l}25.75 \\
3.26\end{array}$ & $\begin{array}{l}6.56 \\
5.44\end{array}$ & $\begin{array}{l}1.08 \\
0.94\end{array}$ & $\begin{array}{l}10.14 \\
19.67\end{array}$ & $\begin{array}{l}0.44 \\
0.42\end{array}$ & & Attached Soil \\
\hline $\begin{array}{l}\text { Shot } 3 \\
\text { Weight \% } \\
\text { Atomic } \\
\%\end{array}$ & $\begin{array}{l}29.68 \\
69.41\end{array}$ & $\begin{array}{l}10.31 \\
9.63\end{array}$ & $\begin{array}{l}1.57 \\
1.05\end{array}$ & $\begin{array}{l}55.09 \\
11.21\end{array}$ & & $\begin{array}{l}0.99 \\
1.38\end{array}$ & $\begin{array}{l}2.35 \\
7.32\end{array}$ & & & Smooth Surface \\
\hline $\begin{array}{l}3,2 \\
\text { Weight \% } \\
\text { Atomic } \\
\%\end{array}$ & $\begin{array}{l}29.90 \\
67.89\end{array}$ & $\begin{array}{l}10.29 \\
9.32\end{array}$ & & $\begin{array}{l}55.94 \\
11.05\end{array}$ & & & $\begin{array}{l}3.88 \\
11.74\end{array}$ & & & Surface \\
\hline $\begin{array}{l}3,3 \\
\text { Weight \% } \\
\text { Atomic }\end{array}$ & $\begin{array}{l}24.25 \\
66.69\end{array}$ & $\begin{array}{l}10.58 \\
11.62\end{array}$ & & $\begin{array}{l}63.39 \\
15.17\end{array}$ & & & $\begin{array}{l}1.78 \\
6.52\end{array}$ & & & Surface Edge \\
\hline
\end{tabular}




\section{Backscatter $x$-ray spectroscopy data derived from a W composite shot fired and aged in Silt (uncrusted).}

\begin{tabular}{|c|c|c|c|c|c|c|}
\hline Silt Un-Crusted & & & & & & \\
\hline Element & $\mathrm{C}$ & $\mathbf{O}$ & $\mathbf{C a}$ & $\mathbf{W}$ & $\mathrm{Sr}$ & Location Description \\
\hline $\begin{array}{l}\text { Shot } 1 \\
\text { Weight \% } \\
\text { Atomic \% }\end{array}$ & $\begin{array}{l}7.30 \\
26.52\end{array}$ & $\begin{array}{l}16.88 \\
46.08\end{array}$ & $\begin{array}{l}11.02 \\
12.01\end{array}$ & $\begin{array}{l}64.80 \\
15.39\end{array}$ & & Smooth Surface \\
\hline $\begin{array}{l}1,2 \\
\text { Weight } \% \\
\text { Atomic } \%\end{array}$ & $\begin{array}{l}8.98 \\
28.06\end{array}$ & $\begin{array}{l}20.26 \\
47.55 \\
\end{array}$ & $\begin{array}{l}12.49 \\
11.70\end{array}$ & $\begin{array}{l}54.75 \\
11.18 \\
\end{array}$ & $\begin{array}{l}3.52 \\
1.51 \\
\end{array}$ & Rough Surface \\
\hline $\begin{array}{l}1,3 \\
\text { Weight \% } \\
\text { Atomic\% }\end{array}$ & $\begin{array}{l}9.63 \\
28.95 \\
\end{array}$ & $\begin{array}{l}21.14 \\
47.72 \\
\end{array}$ & $\begin{array}{l}12.57 \\
11.33 \\
\end{array}$ & $\begin{array}{l}52.63 \\
10.34\end{array}$ & $\begin{array}{l}4.03 \\
1.66\end{array}$ & Rough \\
\hline $\begin{array}{l}\text { Shot } 2 \\
\text { Weight \% } \\
\text { Atomic\% }\end{array}$ & $\begin{array}{l}6.47 \\
22.26 \\
\end{array}$ & $\begin{array}{l}19.54 \\
50.49 \\
\end{array}$ & $\begin{array}{l}13.17 \\
13.58 \\
\end{array}$ & $\begin{array}{l}60.82 \\
13.68 \\
\end{array}$ & & Smooth \\
\hline $\begin{array}{l}2,2 \\
\text { Weight \% } \\
\text { Atomic \% }\end{array}$ & $\begin{array}{l}5.11 \\
17.12 \\
\end{array}$ & $\begin{array}{l}22.61 \\
56.87 \\
\end{array}$ & $\begin{array}{l}12.99 \\
13.04 \\
\end{array}$ & $\begin{array}{l}59.28 \\
12.97 \\
\end{array}$ & & Rough Surface \\
\hline $\begin{array}{l}2,3 \\
\text { Weight } \% \\
\text { Atomic } \%\end{array}$ & $\begin{array}{l}9.83 \\
30.11\end{array}$ & $\begin{array}{l}19.98 \\
45.93\end{array}$ & $\begin{array}{l}12.65 \\
11.61\end{array}$ & $\begin{array}{l}53.68 \\
10.74\end{array}$ & $\begin{array}{l}3.86 \\
1.62\end{array}$ & Smooth \\
\hline $\begin{array}{l}\text { Shot } 3 \\
\text { Weight \% } \\
\text { Atomic \% }\end{array}$ & $\begin{array}{l}7.94 \\
26.09\end{array}$ & $\begin{array}{l}19.07 \\
47.04\end{array}$ & $\begin{array}{l}13.36 \\
13.15\end{array}$ & $\begin{array}{l}55.75 \\
11.97\end{array}$ & $\begin{array}{l}3.88 \\
1.75\end{array}$ & Smooth \\
\hline $\begin{array}{l}3,2 \\
\text { Weight } \% \\
\text { Atomic \% }\end{array}$ & $\begin{array}{l}6.48 \\
21.60\end{array}$ & $\begin{array}{l}20.92 \\
52.31\end{array}$ & $\begin{array}{l}13.17 \\
13.15\end{array}$ & $\begin{array}{l}59.43 \\
12.94\end{array}$ & & Smooth \\
\hline $\begin{array}{l}3,3 \\
\text { Weight \% } \\
\text { Atomic }\end{array}$ & $\begin{array}{l}8.73 \\
27.28\end{array}$ & $\begin{array}{l}20.57 \\
48.27\end{array}$ & $\begin{array}{l}12.65 \\
11.85\end{array}$ & $\begin{array}{l}54.68 \\
11.16\end{array}$ & $\begin{array}{l}3.38 \\
1.45\end{array}$ & Smooth \\
\hline
\end{tabular}

